\title{
Spanish Marranism Re-examined *
}

Herman P. SALOMON **

University at Albany, SUNY

\section{THE LITURGY: WORKING HYPOTHESES AND TENTATIVE CONCLUSIONS}

I submit that the snatches of excellently translated authentic Jewish liturgy known only to a limited number of Mora family members, not found in inquisitorial trials of any other Peninsular tribunals, originated in a manuscript anthology of daily and sabbath prayers in Spanish translation, or in a fragment thereof. The hypothesis of an oral transmission via earlier generations to just these few is untenable. Even less credible is Amiel's repeated appraisal of these prayers as éléments naufragés ('flotsam and jetsam'), which somehow survived the shipwreck of Castilian Jewry. Take the Grace after Meals. How can one possibly imagine $e . g$. the rarely recited "prayer for the guest" to have survived intact by way of secret oral transmission to only Francisco de Mora Molina and Rodrigo del Campo? Is it not obvious that the "Quintanar Grace," such as it is, did not emerge from the mists of the past, but rather that it was haphazardly copied from a manuscript source relatively close in time to the inquisitorial persecution of the Mora family?

Accordingly, this part of the "Quintanar liturgy" is best understood as deriving ultimately from a late $15^{\text {th }}$ century Spanish translation of the daily and sabbath services, supplemented by one piece of apparently traditional folklore ("If you knew and understood what is one"), yet known to only two defendants. In addition, there were a number of other compositions, not traditionally, specifically or exclusively Jewish. The directions for "three steps backward and forward" after reciting the 'Amidah, for covering the eyes while saying the Shema', all were contained in the book. ${ }^{632} \mathrm{We}$ are in the presence, not of texts gradually

* El criptojudaísmo castellano Reexaminado (final). - Continuación de Sef 67 (2007), $111-154$ y $367-414$ y $\operatorname{Sef} 68$ (2008), 105-162.

** herman_prins_salomon@hotmail.com

${ }^{632}$ Such information is provided by many Sephardic prayer books, e.g. Sefer tefilat ha-ḥodeš ke-minhag Qahal Qadoš Sefardim (Leghorn 1928). Cf. AMIEL, "Marranisme” II, 491-492. 
eroded by faulty memory and mechanically modernized, but of innovative and competent adaptations from Hebrew, made by someone who was thoroughly at home with the Spanish Jewish idiom and vocabulary of his time. As we have seen, Rodrigo del Campo does state that at one time he owned a manuscript compendium of prayers, which may well have been a copy. His brother Juan also owned a compendium -brought from Quintanar to Alcázar- from which he in turn copied prayers. Yet there are grounds for hypothesizing that the ultimate source of their memorized liturgy did not even originate in Castile. Let us look at the evidence, culled from the records of the inquisitorial visitation of Alcázar de Consuegra (September 1590 - February 1591).

The day after her first session with the Toledan Inquisitor Andrés de Alava, on January 9, 1591, Isabel de Segura came forward voluntarily. She declared that her husband, the escribano ("notary public') Francisco de Vega "Veguilla," now undergoing his proceso in Toledo, who "loved to acquire and read books" had brought from Granada eight years earlier, a book que se le dijo a esta que trataba de las cosas que hacían los que se iban a el infierno. ${ }^{634}$ She remembered that it was bound in parchment and of demy size. Francisco de Vega was a close friend of Francisco Rodríguez de Armenia, also arrested by the Toledo tribunal, married to Mari López de Mora. She said she was afraid her silence would be held against her if her husband revealed the information.

The Inquisitor, obviously aware that he had struck gold, unsuccessfully pressed various relatives who according to Isabel, had seen or handled the volume, to precisely detail its contents and present whereabouts. Isabel de Buelba consecutively suggested a book of coplas entitled Castillejo; one entitled Clarigua; one that told of Calisto, Melibea and other lovers, denizens of hell. Thereupon the Inquisitor remarked that "the book he is asking her about is quite different." ${ }^{635} \mathrm{He}$ finally heard Ana de Buelba describe it as "a small book of prayers and meditations." Other witnesses simply identified it as a "book of the Law of Moses."

${ }^{633}$ See AHN Inq. leg., 188, no. 1 (Francisco de Vega "Veguilla"), preliminary denunciations extracted from the records of the visitation. On this visitation see AMIEL, "Marranisme" I, 222-223. His opinion that Alava's visitation ended at the end of November 1590 should be revised.

${ }^{634}$ See above Catalina de Villanueva's aside to the Inquisitor after reciting the Shema': "Sir, release me from the Sima, release me from hell." Francisco went on "si algun hombre del campo o alguna bestia leyera por el libro que lo tubiera a mal." In his Alcázar and Toledo confessions (before Inquisitor Andrés de Alava, November 24, 1590 and before Inquisitor Pedro de Zárate, January 8, 1591, respectively) Francisco does not mention the book and professes to recall but minimal scraps of Jewish prayers "learnt from his mother." Francisco was reconciled at the Toledo Auto of June 9, 1591 without having had to answer the accusation.

${ }^{635}$ El libro que se le pregunta es muy diferente de los que dice. 
For that matter, were it not for the sole testimony of his daughter María de Mora, its recent interpretation by Carsten Wilke and my subsequent analysis, I would not have found out that Diego de Mora derived his knowledge of Passover from Villegas' Flos Sanctorum, hot off the press. ${ }^{636}$ Were it not for the Inquisitors' confiscation of Rodrigo del Campo's Boullé Bible and my own consultation of a rare surviving copy, I would not have discovered that Rodrigo translated two of his purportedly "inherited Jewish prayers" from it. Were it not for Alonso del Campo el viejo's stray remark, who would have thought that the "converso prayer" transcribed by Levine-Melammed from a Toledo proceso, the pseudo-Psalm beginning Enllena Señor con gozo mi boca, ${ }^{637}$ was culled from a Catholic Book of Hours? Other stray remarks by Juan López de Armenia I identify the cento of psalm verses beginning En mi tribulación llamaré al Señor ${ }^{638}$ with a Catholic psalter and another "psalm," beginning Señor Dios nuestro que sacaste tu pueblo, with Ambrosio Montesino's Epístolas y Evangelios por todo el año (Antwerp 1544). ${ }^{639}$

On the other hand, as I have just stated, a number of prayers making up the totals are without any apparent Jewish inspiration. It is their lack of specifically Catholic references, however, that allows them to pass for "Jewish" when it suits the Inquisitors or the confessants. They include a few products of pious sentiment and life-style, within the $16^{\text {th }}$ century surge of creativity in the vernacular pioneered by Luis de Granada, Luis de León, Juan and Teresa of Ávila and may all have been culled from contemporary works of Catholic piety. ${ }^{640}$ However, on

${ }^{636}$ It is somewhat paradoxical that Alonso de Villegas dedicated his Flos Sanctorum to Gaspar de Quiroga, Cardinal Archbishop of Toledo and Inquisitor General (1573-1594).

${ }^{637}$ See Levine-Melammed, “Judaizers and Prayer,” 281, 293-294. It was recited as well by Alonso's son Diego (ADC leg. 324, no. 4653), by Elvira Ruiz of Alcázar (AHN Inq. leg. 181, no. 14) who claims her mother Mari López de Mora taught it to her; by Lope de Mora Carrillo "el casado" (extract in ADC leg. 329, no. 4703b, Francisco de Mora Carrillo, posthumous), attributed to the teaching of his father, Lope de Mora. Neither Révah nor Amiel refers to it. Cf. LEVINEMelammed, "Judaizers and Prayer," 278, 280.

${ }^{638}$ Cf. En mi tribulación llamé al Señor, por eso no temeré lo que me puede hacer el hombre (Lope de Mora Carrillo, "el casado," extract in ADC leg. 329, no. 4703b).

${ }^{639}$ See ADC leg. 283, no. 3946. Cf. RÉvaH \& WILKE, Un écrivain, 173; AMIEL, "Marranisme” II, 518-519, 565, 568 .

${ }^{640}$ See "La liturgie crypto-juive," 21: Señor, haz bienauenturada esta ánima pecadora; 25 : Blancas y descansadas están aquellas almas; 29-31: Alabado seais vos, Señor, que me levantastes (also AmIEL, "Marranisme" II, 570); 32: Bendito seáis vos, Señor, que me dejastes ver este medio día (also AmIEL, "Marranisme” II, 571); 36: Bienauenturada es la persona. Variant and expanded versions of Bienaventurada es la persona may be found in the extracts from the procesos of Alonso del Campo (ADC leg. 330, no. 4722, Isabel de Villaescusa, 20r); in the procesos of his 
February 20, 1592, an original, distinctly Jewish prayer in the form of a sonnet (the only one of its kind I have found) uniquely surfaces in the proceso of Juan del Campo II, Francisco de Mora Molina's 22-year old nephew and cellmate, whom we have met elsewhere:

Soberano rector de lo criado

Del gentílico error no conocido

Tan digno siempre de ser muy temido

Cuanto ser de todos muy amado.

Si la judaica culpa te ha enojado

Y por ello tu pueblo es afligido

Acuérdate señor que es escogido

Y por tu fuerte diestra libertado.

Pecaron nuestros padres y pecamos

Por lo cual justamente nos afliges

Más no mires señor nuestras maldades

Dígase entre las gentes, pues llamamos,

Que con misericordia nos corriges

$\mathrm{Y}$ aceptas las contritas voluntades. ${ }^{641}$

His father, Alonso del Campo el viejo, supposedly taught Juan this beautiful and profound poem but it is not among the prayers confessed by him. If it was composed, as I suppose, by Juan's uncle Rodrigo del Campo, we can only guess as to why the latter did not recite or transcribe it in the course of his own trial.

son Diego del Campo (ADC leg. 24, no. 4653: August 27, 1590); Cristóbal de Mora Molina, son of Juan de Mora and Isabel Falcón (ADC leg. 321, no. 4621, 21v); María de Mora (Carrillo), daughter of Juan de Mora and Catalina Carrillo; Francisco Ruiz de Armenia (ADC leg. 322, no. 4631); Leonor Ruiz, his daughter (ADC leg. 551, no. 6918). It is mentioned by its incipit in several procesos as a core prayer, e.g., Ana de Mora, daughter of Francisco de Mora the Elder; Rodrigo del Campo, claiming to have learnt it from Diego de Mora (see "La liturgie crypto-juive," 36); Juan del Campo; Lope de Mora (Carrillo), son of Juan de Mora, in his father's posthumous proceso (ADC leg. 331, no. 4733); Apolonia de Barrionuevo (in the proceso of Isabel de Villaescusa: ADC leg. 330, no. 4722).

${ }^{641}$ See ADC leg. 325, no. 4663 (Juan del Campo). The poetical prayer has gone unnoticed by Révah \& Wilke and Amiel. 
Altogether some ten "voices" are involved in the five "hard core" Jewish or Judaic pieces. I believe that we are dealing with various stages. An imaginative, fairly literal written translation fragment came into someone's (Diego de Mora's?) hands, who copied it out. It had some characteristically Judeo-Spanish vocabulary (e.g. enreinar, abastado), probably sported the folkloristic Jewish forms Dio and el Dio. Francisco de Mora Molina, his brother Juan de Mora and a few others learnt by rote parts of that same translation and recited them to the Inquisitors. This corpus, in turn, was here and there "improved" upon by their cousin, Rodrigo del Campo.

We must remember that Rodrigo del Campo was an intellectual, a Master of Grammar and a man of letters. This would account for the fact that his versions, essentially the same as Francisco de Mora Molina's, Juan de Mora's, etc., and even filling in lacunae, are consistently more literary and flowery.

We can reject, I believe, out of hand the romantic notion of a "chain of tradition" linking these prayer texts to their reciters' (supposed) Jewish ancestors of two centuries earlier.

The following considerations -in addition to or repeating those that have already been stated- lead me to conclude that the corpus of authentically Jewish prayers confessed by the defendants of the Mora trials is of late $15^{\text {th }}$ century vintage.

The few Hebrew reminiscences it contains are precisely those that appear, transliterated into Latin letters, in Ferrara 1552. Aside from these words, there is not a single survival of Hebrew in the corpus. With due tentativeness, one is tempted to posit the existence in the manuscript prayer book of a few selected transliterations, analogous to those of Ferrara 1552. Thus, while it is possible that the Quintanar reciters who attempted to reproduce them in Hebrew had a tradition or a subjective sense of their enhanced sanctity, they might have done so simply because the written text from which they mechanically borrowed had them in transliterated Hebrew.

Though the Talmud had ruled that one is allowed to recite prayers in any language (bSotah, 32b), nevertheless synagogue prayer and liturgy was confined almost exclusively to Hebrew and Aramaic. To this day, with the almost universal availability of translations into one's native language on pages facing the Hebrew, many worshippers do not look at the translations even though they do not understand the words they are uttering. If any memory of Jewish liturgy survives in adults who have abandoned all religious practices, they tend to be limited to smatterings of Hebrew absorbed without any understanding of their meaning. Quite frequently among former worshippers of Sephardic synagogues 
where communal song is so much more part of the service than in the Askenazic ones, all that is left consists of High Holy Day melodies hummed after a few initial memorized words in Hebrew of which they never knew the meaning. We should remember that few Jews maintain daily home devotions into adulthood. Moreover, the average Jews then and now rarely frequent the weekly Sabbath and even less the daily synagogue service. It is only on the High Holy Days, especially on the Day of Atonement, that most or all find their way back to the synagogue. But, as stated earlier on, the authentically Jewish part of the Quintanar liturgy is (with two or three exceptions) ${ }^{642}$ restricted to a few core items from the daily and sabbath prayers. This "selective amnesia" further confirms their adoption from a written source, which had suddenly become available.

Until 1900 no complete or partial translation of the liturgy into Spanish or Portuguese either printed or in manuscript had come down from pre-expulsion Spain or Portugal. ${ }^{643}$ In that year emerged the single surviving quire from such a manuscript in Spanish, in Latin letters, possibly -but not necessarily- directed to women. ${ }^{644}$ As stated above, it contains part of the Hallel and part of the Musaf of Rosh Hodesh and includes a few transliterated Hebrew words, left untranslated; also the Jewish designations of the deity: Adonai and Dio. This shows it was intended for the devotions of Jews. ${ }^{645}$ The Spanish scholar Fidel Fita, who published the surviving fragments, suggested that the manuscript dated from the $15^{\text {th }}$ century. He established that the prayer book from which the quire was violently torn had over 242 pages. The Italian scholar Margherita Morreale, who analyzed part of the fragments, posited "the last decades of the $15^{\text {th }}$ century" and shows -by way of comparison with $16^{\text {th }}$ century printed prayer books in

${ }^{642}$ We have seen (supra 18.4) that Francisco de Mora Molina's "If you knew" was unrelated to the Haggadah. Cf. however, supra n. 340 and Amiel ("Marranism" II, 552). (The ditty quoted there is also found in ADC leg. 330, no. 4722, posthumous proceso of Isabel de Villaescusa, intr. prayer confession of Apolonia de Barrio Nuevo.) We have also seen (supra 18.3) that Esperaré en el Señor from the New Year of Day of Atonement service crept in accidentally or by error.

${ }^{643}$ RIERA I SANS, "Oracions en català dels conversos," 348 refers to undated Oxford Ms. Bodl. Or. 9: Hebrew prayers with interlinear Catalan translation.

${ }^{644}$ There was a Jewish audience in $15^{\text {th }}$ century Spain for Spanish translations in Latin letters of Jewish books, as exemplified by the mid- $15^{\text {th }}$ century Spanish version of the Kuzari, M. LAZAR, ed. (Culver City, Ca 1990), replete with transliterated, untranslated Hebrew and Hispanized Hebrew terminology. See also the mid- $15^{\text {th }}$-century Spanish Kișșur Tur Orah Hayyim and Pirqe Abot in Lazar (ed.), Sefer Tesubah. The early $15^{\text {th }}$ century Spanish Bible translation E19 was obviously done by Jewish scholars for Jewish readers.

${ }^{645}$ Révah of course assumes it was intended for conversos. See Annuaire EPHE IV, $1963-$ 1964 (1963), 193. Curiously, according to both the original and later substituted page numbers of the fragments the Hallel follows the Musaf. 
Spanish-, that these late $15^{\text {th }}$ century fragments and the $16^{\text {th }}$ century publications represent independent efforts, minimally related to each other.

It was only in 1552 that very literal Spanish translations of the Sephardic prayer book appeared in print for the first time. These (Venice 1552 and Ferrara 1552) were principally destined for the provisional use in synagogue by Portuguese New Christians who adopted Judaism there, had as yet no notion of Hebrew but wanted to follow the Hebrew service. The making of such super-literal Spanish translations, then, is a typically $16^{\text {th }}$ century Italian phenomenon. ${ }^{647}$ They were never part of the synagogue service. Former New Christians integrated into the Sephardic communities, and certainly their offspring born and raised as Jews, joined in the communal Hebrew prayers and chants.

\section{1: A Possible Explanation}

Jean-Pierre Dedieu eloquently delineates the transformation of inhabilitación into "blood impurity":

During the first half of the $16^{\text {th }}$ century a small minority of the conversos were at the centre of current events: those who had personally experienced 'reconciliation' at an Auto de Fe; those, above all, whose ancestors had been sentenced by the Holy Office. When the problem underwent a change in kind and 'unfitness to hold office and to receive honours' was transformed into 'blood purity,' it was they, I believe, who provided the bulk of those New Christians who were to be excluded from society. The others had been forgotten. The Inquisition, indeed, functioned as a marker, in two respects. On the one hand the memory of an inquisitorial condemnation is the only certain, demonstrable element which allows society to assert as a fact a family's New Christian status during the second half of the $16^{\text {th }}$ century, when the memory of ancestral conversion had been forgotten. On the other hand, within the converso group, those who during the preceding two generations had been obliged to purchase privileges or who had been tried on the count of infringement of disqualification were particularly prone to being pointed out. Their permanent unfitness maintained the difference and prevented forgetting, synonymic with assimilation. It was the relay station which allowed the memory of their status to partially pass through the half century which separates the anti-New Christian campaigns of the end of

${ }^{646}$ See Fita, "Fragmentos de un ritual hispano-hebreo;" Morreale, "Libros de Oración."

${ }^{647}$ See SAlomon, "Was there a Traditional Spanish Translation of Sephardi Prayers Before 1552 ?," $78-97$. These $16^{\text {th }}$ century books were reprinted well into the $18^{\text {th }}$ century for the use of newcomers from the Peninsula. 
the $15^{\text {th }}$ century from the 'blood purity' statutes of the middle of the $16^{\text {th }}$ century." ${ }^{648}$

This may well describe what occurred in Quintanar. During the thirties of the $16^{\text {th }}$ century, the Toledan Inquisition conducted visitations in its district to establish precise genealogies of conversos and to discover children of parents condemned by the tribunal. Once identified such children could be charged for violation of inhabilitación, ensuring their demotion to second-class status. There must have been feuds, enmities, and grudges in Quintanar, which prompted the sending of denunciations for infringement of inhabilitación to Cuenca. The question remains, however: why only here and not elsewhere in the districts of Toledo and Cuenca? ${ }^{649}$ Since according to Dedieu, so many $16^{\text {th }}$ century New Christians succeeded in integrating, what was the tipping point for our subgroup? Here, c. 1564, the Cuenca Inquisition, which had lain dormant as regards New Christians in Quintanar for four decades, launched a campaign against the Moras, that resulted in public disgrace, even banishment. Perhaps the most decisive family event was the paradigmatic trial of Elvira del Campo, 1567-1568, her ghoulish torture sessions and reconciliation at the Toledo Auto of June 13, 1568. It does not take much to evaluate its trauma on her brother, Rodrigo del Campo.

Thus we have the fertilization for the birth of a "Jewish identity" among the conversos of Quintanar. As luck would have it, they were numerous, rather prosperous, all interrelated. They counted no priests, friars or nuns in their ranks, had insufficiently intermarried with Old Christians, were engaged in taxcollection and thus, in a Jew-less but rabidly anti-Jewish provincial society, had kept -or newly acquired-a Jewish reputation. ${ }^{650}$ This posed a unique challenge

648 "Hérésie et pureté de sang: l'incapacité légale des hérétiques et de leurs descendants en Espagne aux premiers temps de l'Inquisition," in J.-P. Almaric, ed., Pouvoirs et sociétés dans l'Espagne moderne (Toulouse 1993), 160-176: 176. The translation from French is my own. Cf. V. PArELlo, Les Judéo-Convers, Tolède XVe-XVI siècles. De l'exclusion à l'intégration (Paris-Montreal 1999), 79.

649 The Murcia tribunal's rampage against native Judaizing 1560-1568, due to the disappearance of the procesos, defies analysis. Cf. J. BlázQuez Miguel, Catálogo de los procesos inquisitoriales del Tribunal del Santo Oficio de Murcia (Murcia 1987), 28-47, based on Madrid BN Ms. 9175 (Relación del auto de la fe que se hizo por el santo oficio en Murcia domingo de Lázaro 15 de marzo de 1562), f. $257 v$.

${ }^{650}$ See T. F. GLICK, "On Converso and Marrano Ethnicity,” in B. R. GAMPEL, ed., Crisis and Creativity in the Sephardic World. 1391-1648 (New York 1997), 59-76: 59-61. An interesting comparison could be made with the family, educational and economic background of Pedro del Campo, regidor of Quintanar, whose first marriage to a convicted New Christian and "drop of converso blood" were not deemed sufficiently indicative of Jewish ethnicity to justify adding Judaizing as a count against him. See ADC leg. 327, no. 4690. Cf. RÉVAH \& WILKE, Un écrivain, 107, 444, n. 4 to 107 (correct "parfois regidor" to "regidor perpétuel"; correct "biens de sa femme défunte" to "l'argent que lui avaient confié Joana et Beatriz de Mora"). 
for the Inquisition in one of its self-appointed roles: to purify Spain of tainted "Jewish blood." Inquisitors' motivations are complex: lust for power, laziness alternating with bureaucratic zeal and, no doubt the principal element, shared by the Spanish hoi polloi whose deepest emotion they nourished and incarnated: to wit, pure, unadulterated hatred of anything, everything, anyone, everyone "Jewish" or originating in Judaism. According to the dominant ideology, New Christians, identified as such by pública voz y fama ('public opinion and reputation'), could never be good Christians. ${ }^{651}$ No matter how far back in time their ancestral conversion, its very fact rendered their lineage illegitimate and their origin perverse. The only unquestionably legitimate origin, which is that of the Old Christian commoners, is one that cannot be historically determined, that has no genealogy: a non-memorial antiquity. Thus the conversos of whatever known lineage were turned into society's opposite pole, rendering possible the cohesion of the majority. New Christian ethnicity was identified as the poison that permanently menaced society. The laws of blood purity were its antidote. Converted Christians or their descendants, however remote the conversion, exercise ipso facto a negative and heretical activity in the Church, due to their Jewish origin. And they must therefore be excised from the body of the faithful and ultimately from society: they must become pariahs. This process, called the "Tibetization of Castile" by a modern historian, had the obvious approbation of King Philip II, during whose reign (1566-1598) it took place. ${ }^{652}$

All this predisposes one to conclude that the Inquisition did not "discover" Marranos in Quintanar de la Orden; it created them.

Let us now examine the question of motivation on the other side. How to explain the presence of Jewish liturgical material and perhaps practices in Quintanar de la Orden, among these families who had been Catholic for centuries? No doubt, some sought solace in the Bible and identified with its worthies. In his section on "Culture and Readings" Amiel calls to mind the atmosphere of such a biblically inspired religious revival in Quintanar. ${ }^{653}$ But there was

${ }^{651}$ A neighbor's denunciation during the visitation of Quintanar on September 10, 1590 (ADC leg. 551, no. 6918, Leonor Ruiz) runs: Y que siempre había tenido mala sospecha de la cristiandad de esta gente como son notoriamente conversos y por no vivir en sus casas como los demás cristianos.

${ }^{652}$ See J. I. Gutiérrez Nieto, "La discriminación de los Conversos y la Tibetización de Castilla," Revista de la Universidad Complutense, 22 / 87 (1973), 99-129; J. ConTRERAs, "Limpieza de sangre: los discursos de la retórica y la importancia de las realidades," in Felipe II y el Mediterráneo. Los grupos sociales (Madrid 1999), 481-501.

${ }^{653}$ AMIEL, "Marranisme" II, 509-534, an expanded revision of RÉVAH \& WILKE, Un écrivain, 101-106. 
more to it than a "self-fulfilling prophecy." ${ }^{654}$ There ran through Spain (and, indeed, the entire Spanish Empire) a strain of spiritual restlessness, endemic to the Iberian renaissance. ${ }^{655}$ It would not be amiss to characterize Judaizing (in the total absence of inherited Jewish tradition) as one of the forms taken by Protestantism in post-Tridentine Iberia: a revolt against Catholic tyranny. This Judaizing was a $16^{\text {th }}$ century innovation, catalyzed by the convergence of various currents and influences, which (pace the Inquisition) did not necessarily include Jewish ancestry. The study of $15^{\text {th }}$ century biblical fundamentalism growing within Spanish society is still in its infancy. ${ }^{656}$ What seems clear is that the "Jewish" (i.e., OT) element of Catholicism must have had quite a following, to judge from the popularity among Christians, whether Old or New, of such works as the 3500-page "Mirror of Consolation" by Juan de Dueñas, with its 40 editions, 1540-1591.

The revival spread to New Spain (Mexico). In the early 1560's a theological debate in verse concerning the continued validity of the "Old Law" raged among Spanish poets, recent immigrants to New Spain. One Fernán González de Eslava, an Old Christian, stated the dilemma as follows: "If the Old Law was bad, why did God give it? And if it was good, why should it not be so any longer?" His décima provoked replies in kind by two other poets. González de Eslava's décima wonders why Jews should not merit this world's respect and salvation in the next for observing a Law given by God. Two décimas with surrebutters followed. Judges, lawyers, the entire upper crust of Mexican society read the décimas and followed the debate. Soon the Holy Office intervened, called for denunciation of all those who had copies in their possession and instituted proceedings. ${ }^{657}$ But these bards of Mexico are on a different social, theological and intellectual level from the hapless Moras of New Castile.

And yet even in their spate of seemingly mindless confessions, delations and liturgical recitations we meet up with echoes of a comparable dilemma. In his proceso Rodrigo del Campo declares (ironically?) to Inquisitor Francisco de

654 "A false definition of a situation, evoking a behavior which makes the originally false definition come true." See R. K. Merton, "The Self-fulfilling Prophecy," The Antioch Review 8 (1948), 193-210: 206.

${ }^{655}$ See M. BAtaillon, Erasmo y España: Estudios sobre la historia espiritual del siglo XVI (México 1966).

${ }^{656}$ See L. M. Girón-Negrón, Alfonso de la Torre's Visión Deleytable, Philosophical Rationalism and the Religious Imagination in $15^{\text {th }}$ Century Spain (Leiden 2001).

${ }^{657}$ See J. Toribio Medina, Historia del Tribunal del Santo Oficio de la Inquisición em México (México DF 1952), 54-57, 398. 
Arganda:

Y aun que no sabía latín, por ser aficionado a leer en la Biblia, había venido a entender lo que leía y que no sabía que guardar los sábados fuese contra lo que tiene y enseña la madre iglesia de Roma. Porque si dijera no guardarás los sábados, como dice no matarás, no hurtarás, bien lo supiera, y que él tenía y creía todo lo que tiene y enseña nuestra sancta madre iglesia de Roma. Y que una de las oraciones que sabía era del tenor siguiente: diez mandamientos, se guardan los sábados. ${ }^{658}$

On September 9, 1590, Inquisitor Arganda wrote to the Suprema in Madrid:

Según lo que de las confesiones de Rodrigo del Campo va resultando -aún que sacadas con mucha dificultad y trabajo- y las hace con toda la equivocación que él puede, resulta gran sospecha contra él de dogmatizador de más de lo que por la declaración de Catalina de Villanueva (mujer de Francisco de Mora el viejo) resulta, porque sin haber estudiado entiende el latín de la Biblia como si hubiera estudiado y declara que ha sido muy aficionado a leer en latín y en ella.

The wave of arrests at Quintanar began in 1588. One terrorized group of Moras after another disappeared into the inquisitorial dungeon of Cuenca. The vicious cycle of reciprocal false denunciations and spurious confessions, like a whirlpool sucked all the victims, young and old, men and women into its vortex except for the few heroes who denied everything to the bitter end and in two cases were murdered by the mob before their execution. When Francisco de Mora Molina yielded at the Auto on August 12, 1590, he re-entered the vortex with the understanding that if he "revealed all and denounced everyone" the inquisitors might spare his life. We -the writer and readers of this essay- know that this was an inquisitorial decoy, but -aside from Francisco's denunciations, which landed almost all the Moras of Quintanar behind bars- how did the Inquisitors intend to use the "Encyclopedia of Marranism" furnished them by Francisco? We know the use our historians, Révah and Amiel, made of it to prove to their own and their faithful's satisfaction the truth of the marranic myth: vive le marranisme!

${ }^{658}$ See ADC leg. 321, no. 4627, 91 $r$. Further on [134]: Bien sabe que [Dios] no manda guardar [los preceptos] más de que en algunos libros confesionales y otros ha visto en los [diez] mandamientos, como dicen en el tercero: Sabata santificeo [...] que quiere decir que se santifiquen los sábados; [135] Si la sancta madre iglesia de Roma dijera no guardarás los sábados, como dice no matarás y no hurtarás, supiera que el guardar el sábado era contra lo que tiene y enseña.

${ }^{659}$ See ADC leg. 327, no. 4689 (Isabel de Mora Carrillo). 
All this does not explain why the defendants recited prayers to the Inquisitors. I suspect that the latter, in spite of their "professional" interest, could not have cared less. Still, they allowed three reciters, at their own request, to fill in the gaps left in their oral recitation by transcribing some of the prayers in extenso and with great attention to detail. ${ }^{660}$ What could have impelled these three? Révah never stops to ask that question. Charles Amiel ventures a simplistic psychological explanation: pour en finir ('to have done with it'). ${ }^{661}$

Considerations of quite another order condition my own answer. In the first place, the "Quintanar liturgy" was limited to a sub-group, consisting principally of Francisco de Mora Molina, his brother Juan de Mora, his Aunt Catalina de Villanueva, his five sisters and Rodrigo del Campo; to a much lesser degree Rodrigo's brother Alonso and Leonor Ruiz. Thus, the case for a collective preservation throughout many generations of the daily Shema 'among 100 "voiceless" of Quintanar rests principally on the inquisitorial confessions of eight persons, five of them siblings, two first cousins and an aunt.

It must have provided some of them a certain gratification to flaunt it all in their persecutors' face. In their recitations and transcriptions, along with showing the required remorse, they may well have taken pride in their accomplishment. We are dealing, after all, with Spaniards and a vindication of wounded honra. As to Francisco de Mora Molina, he was a walking repertory, le déclarant incontestablement le plus complet ('beyond all question, the most complete informant'). ${ }^{662}$ While pinpointing a motivation here is beyond my competence, ingratiating himself with the Inquisitors seems feasible. A careful analysis of his two letters to Inquisitor Arganda included in this study may help us shade in the perspective provided by earlier historians. If only we had

${ }^{660}$ See ADC leg. 321, no. 4627 (Rodrigo del Campo, October 12, 1591): Dicho que suplica a su Señoría se le de papel y tinta para escribir de su mano las demás oraciones que sabe, por que estará más en memoria de ellas. Cf. ADC leg. 318, no. 4587 (Juan de Mora, January 21, 1589): Dijo que tiene tan flaca memoria que no se le acordara bien, que le dejasen recoger y que el pensaría y la escribiría [...] y los demás que supiese [...]. Cf. ADC leg. 330, no. 4722 (Alonso del Campo el viejo in proceso of Isabel de Villaescusa): Dijo que él ha escrito las oraciones lo mejor que ha podido y se le ha acordado, y escribió los d. pliegos de papel que en el audiencia pasada se le habían dado [...].

661 "The individual prayer of the Marranos [...] was destined to remain tucked away in memories and in hearts, were it not for the stubborn inquisitorial interrogations and the despair of the prisoners who, ensnared by relatives' denunciations, ended up by spilling the beans, in order to have done with it." See AMIEL, "Marranisme" II, 489. In fact, it does not appear to me from what the procesos reveal that the prisoners were coerced or "ensnared" into confessing and reciting the prayers.

${ }^{662}$ AmIEL, "Marranisme" II, 546. 
a better grasp of Francisco's relationship to his more learned cousin, Rodrigo del Campo, and the extent of their reciprocal transmission of texts. The notion that Diego de Mora and his siblings taught their children crypto-Judaism, in the circumstances described, seems to me hardly credible but rather a subterfuge to avoid telling the truth, which escapes me, escaped the Inquisitors and perhaps escaped the confessants themselves. Nor am I fully convinced that Francisco de Mora the Elder and Beatriz de Mora, who firmly denied all charges until sentenced to execution, were not telling the truth.

${ }^{663}$ I thank don Marcelino Angulo, archivero of the ADC, and his assistant don Miguel Ángel Pozuelo, for their friendly reception and sundry assistance. Isaac S. D. Sassoon supplied stringent revisions, unlimited erudition and imaginative sketches. Dr. Carsten Wilke, at my electronic disposal to solve problems of detail, critically appraised the arguments. Dr. Harm den Boer and Dr. António Feijó made salutary queries and suggestions for improvement. I am beholden to my friends Madame Joanie Mendès-France for her careful reading and comments and Senhor Mário Fernandes for the genealogical table. On May 21, 2004 and on May 20, 2005 I gave papers outlining my tentative conclusions at the Conferences on Conversos and Moriscos (Saint Louis University, Madrid Campus). On June 15, 2004 I delivered a lecture at the University of Lisbon entitled "Reaberto o debate entre I. S. Révah e A. J. Saraiva sobre o criptojudaísmo peninsular?" discussing various aspects of my findings (publ. Cadernos Sefarditas 5, 2005, 89-114). 
ADDENDUM Sef 68 (2008), 413-459.

p. 416 , line 13: whereas the mid- $16^{\text {th }}$-century Sephardic Bible and liturgy translations consistently render the Hebrew root פרח ('to burgeon; to spring forth') by enflorecer and the synonymic ציץ ('to flourish') by hermollecer, the medieval Spanish Bibles usually (but not invariably) translate both פריץ מצח by florecer (but we also find reverdecer, re[s?]tollecer, hermollecer, crecer, nacer). For instance, at Isaiah 27,6 where we have פרח side by side, E3 and MRAH respectively supply hermollecerá y florecerá; crecerá y florecerá. Thus, where medieval translators were groping for a satisfactory pair of synonyms, astilar would have filled the bill. Yet only the Quintanar translation provides astilar for פרח. It shares florecer for ציץ in Ps. 92,8 with E3 and BN Ms. 10288. 


\section{APPENDIXES}

\section{Extract from the second proceso of Elvira del Campo, contained in the proceso of Inés del Campo (ADC 320, 4620) (Modernized spelling and punctuation).}

En la ciudad de Cuenca a 17 días del mes de junio de 1591 años, estando los Señores Inquisidores Doctor Francisco de Arganda y el licenciado Francisco Velarde de la Concha en su audiencia de la tarde, mandaron traer a ella de las dichas cárceles de este Santo Oficio a una mujer de la cual siendo presente fue recibido juramento en forma de derecho, so cargo del cual prometió decir verdad de lo que supiese y fuese preguntado en esta audiencia y en las demás que con ella se tuviesen, hasta la definición de su causa. Y preguntada dijo llamarse Elvira del Campo, viuda de Alonso de Moya, escribano vecino de la villa de Alcázar de Consuegra y que esta confesante es vecina de la villa del Quintanar de la Orden, de edad que dijo ser de 65 años, poco más o menos. Y dio su genealogía en esta audiencia y entre otros hermanos que dijo tener a Inés del Campo, vecina de la dicha villa del Quintanar de la Orden. Y respondiendo a su calidad dijo ser confesa y que fue reconciliada por el Santo Oficio de Toledo. Y entre otras preguntas que en esta audiencia se le hicieron y lo que a ellas respondió es lo siguiente:

Preguntado, dijo que no sabe leer ni escribir ni tiene libros y que su hermano Rodrigo del Campo leía a este confesante y a Inés del Campo su hermana libros de caballerías y otros libros de buenos confesos. Que no sabe decir qué libros eran y que no todas veces quería leer, como era escribano y estaba cansado de escribir y leer toda la semana.

Preguntada si sabe o presume la causa por qué ha sido mandada prender y traer a las cárceles de este Santo Oficio, dijo que no sabe y que presume que había sido por alguna cosa que habían dicho de esta confesante.

Preguntada qué es lo qué presume esta confesante que habían dicho de ella. Dijo que podía ser haber dicho que esta confesante había hecho alguna cosa que no debía.

Preguntada qué es lo que podían haber dicho que este confesante haya hecho que esta confesante no debiera. Dijo que podían haber dicho que esta confesante ha hecho alguna cosa de las que han hecho los que han traído presos del Quintanar.

Preguntado qué cosas han hecho los que han traído presos del Quintanar. Dijo que algunas cosas de la Ley de Moisén según que esta confesante ha oído decir.

Preguntada qué cosas son las que han hecho los que han traído presos del Quintanar de la Ley de Moisén que esta confesante ha oído decir. Dijo que ha oído decir que holgaban el sábado y que no comían tocino y que alguna vez mataban alguna res en su casa al revés de como lo hacían los cristianos viejos. Que entiende que era atravesado el cuchillo. Y que guardaban las pascuas de septiembre, que cree que es la pascua que llaman del pan cenceño que se guarda la dicha pascua por haber sacado Nuestro Señor Su pueblo de la cautividad de Egipto. Y que hay otra pascua por la cuaresma que llaman del cordero, y que no sabe de otra pascua más de haber oído decir que 
hay otra pascua que no se acuerda por qué tiempos se guarda ni cómo se llama. Y que las otras pascuas se guardan por tiempo de ocho días cada una, o de siete días y que no sabe por qué se guarda la pascua del cordero y que esta confesante las ha acostumbrado poco y que en verdad que no las tiene en el corazón. Y que como este confesante vino del Santo Oficio de la Inquisición de Toledo, luego como vino -visto que le había corrido tantos trabajos- presupuso a si y estuvo muy determinada de no volver a las cosas de la Ley de Moisén. Y visto que su marido la había desamparado y que no consentía aún que sus hijos le viniesen a ver, y que estando en compañía de los dichos sus hermanos Rodrigo y Inés del Campo, los susodichos hacían las cosas de la Ley de Moisén que tiene dichas y se escondían de esta confesante y no estaban bien con ella porque no las hacía. Y pasado algun tiempo que serían ocho o diez años este confesante -visto que estaban mal con ella y que no tenía adonde irse- determinó de hacer lo que ellos hacían de la Ley de Moisén, siéndole forzoso por lo que tiene dicho aunque no le salía de corazón. Y que así esta confesante no pudiendo -como tiene dicho- hacer otra cosa, después de los dichos ocho o diez años a esta parte, guardó los sábados y dejó de comer tocino y guardó las pascuas del pan cenceño y del cordero aunque el pan cenceño nunca se hizo en casa de los dichos sus hermanos. Y que por el mes de Septiembre esta confesante y los dichos Rodrigo e Inés del Campo sus hermanos ayunaban un ayuno que entiende esta confesante que le llamaban el ayuno mayor, el cual comenzaba con el primero día de la luna de septiembre y duraba diez días. Y que no los ayunaban todos, sino cada uno como podía. Y el postrer día del dicho ayuno llamaban el día mayor y bueno. Y que entraba la pascua que tiene dicha del mes de septiembre a cuatro o a cinco días después de los diez del ayuno, y que entre año ayunaban algunos días y por la cuaresma, y que se ayunaban los dichos ayunos no comiendo ni bebiendo por todo el día de sol a sol puesto. Y se barría y limpiaba la casa los viernes por las tardes y se encendían las candiles y que no ardían más que otras noches. Y que comenzaban a guardar el sábado desde el viernes por la tarde a puesta del sol, y algunas veces más tarde. Y que no se acuerda por agora de otra cosa, ni tiene más que decir. Y amonestada fue mandada volver a su cárcel. Y parece haber pasado ante Cristóbal Simón Ángel, notario.

En la ciudad de Cuenca a 21 días del mes de junio de 1591, estando el Señor Inquisidor Licenciado Francisco Velarde de la Concha en su audiencia de tarde, mandó traer a ella de las dichas cárceles a la dicha Elvira del Campo. E como fue presente se le dijo que ha acordado en este su negocio que deba decir por descargo de su conciencia. E so cargo del juramento que tiene fecho diga en todo verdad.

Dijo que se ha acordado que después que prendieron por este santo oficio a Alonso del Campo, su hermano, que fue por el mes de julio del año prójimo pasado, esta confesante e Inés del Campo su hermana se pasaron a casa del dicho Alonso del Campo con Isabel Romero su mujer. Y estuvieron en la dicha casa como dos meses, poco más o menos, y en este tiempo esta confesante estuvo indispuesta en la cama algunos días de unas sesiones, y desde la dicha cama entendía esta confesante que ayunaban el ayuno del mes de setiembre, porque oía andar revueltas como que aderezaban de cenar. Y a lo que entendió eran Juan, Alonso, Pedro del Campo y la dicha Inés del Campo, hermana de este confesante, y Ana de Mora, hija bastarda de Juan de Mora que servía en la dicha casa. Y esta confesante desde su cama oía como que los dichos días trataban y hablaban de la cena y sentía que la andaban aderezando. Y esto es lo que tenía que manifestar que se ha acordado, y no otra cosa. Y es la verdad, y hace le juramento, que tiene hecho. Y amonestada fue manda[da] volver a su cárcel. Y parece haber pasado ante Cristóbal Simón Ángel, notario. 
En la ciudad de Cuenca a 4 días del mes de julio de 1591, estando los Señores Inquisidores Doctor Francisco de Arganda y el Licenciado Francisco Velarde de la Concha en su audiencia de la tarde, mandó traer a ella de las dichas cárceles a la dicha Elvira del Campo. E como fue presente se le dijo que ha acordado en este su negocio, que deba decir por descargo de su conciencia e so cargo del juramento que tiene hecho diga en todo verdad.

Dijo que "verdad, Señor, que no tengo yo otra cosa que decir más de la que tengo dicho." Y puesta la acusación por esta audiencia por el fiscal, y respondiendo a ella y al $4^{\circ}$ capítulo de ella, que es del tenor siguiente:

Y por rito y ceremonia de la dicha Ley de Moisén, juntamente con las dichas personas sus conjuntas, ha tornado a guardar y festificar los sábados sin hacer obra servil en ellos, comenzando desde el viernes por la tarde puesto el sol, poniéndose tocas y camisa limpia y otras ropas mejoradas y de fiesta, barriendo y limpiando la casa los viernes por las tardes y en ellos en las noches encendiendo los candiles bien fregados con torcidas limpias, mejorándolas de aceite para que ardiesen toda la noche. Y porque cierta pers[ona] que le parecía aquello los mataba, se quejaba de ella a otra persona su conjunta, diciendo que no la quería dejar servir a Dios.

Dijo que es verdad que después que esta confesante vino reconciliada de Toledo pasados más de diez años guardó algunos sábados como tiene dicho juntamente con los dichos Rodrigo del Campo e Inés del Campo sus hermanos, e que no dejaban de hacer algunas cosillas con ellos algunas veces que se ofrecían. Y que es verdad que comenzaban este confesante y los dichos sus hermanos a guardar y holgar los sábados desde el viernes en la tarde puesto el sol. Y que es verdad que barrían y limpiaban la casa esta confesante y la dicha Inés del Campo su hermana los viernes en las tardes algunas veces. Y que en los dichos viernes en la tarde la dicha Inés del Campo su hermana alguna vez limpiaba y aderezaba el candil, y que no dejaban arder el candil más aquellas noches que otras y que esto que dice la persona que mataba el candil era Pedro del Campo, sobrino de esta confesante, hijo de Alonso del Campo su hermano, que algunas veces en los viernes y en otros días estando esta confesante y la dicha Inés del Campo cenando, les mataba el candil por hacerles mal. Y que si supiesen las cosas que el dicho rapaz Pedro del Campo hacía y decía en tiempo de mes y medio o dos meses que esta confesante y la dicha Inés del Campo su hermana estuvieron en casa del Alonso del Campo, hermano de esta, después que prendieron al dicho Rodrigo del Campo, que no le creerían ninguna cosa que dijese.

Respondiendo al $6^{\circ}$ capítulo de la dicha acusación, que es del tenor siguiente:

Y por el dicho fin y respecto juntamente con las dichas personas guardó y festificó tres pascuas de judíos: una por la semana santa que llaman del cordero en que es de creer y presumir que se juntaban y congregaban a sacrificar el cordero y comían pan cenceño. Otra por el mes de Mayo que llaman de las cabañuelas. Otra 15 días de la luna del mes de septiembre, vacando de obra servil en cada una de ellas por tiempo de siete y ocho días por diversos respectos, comiendo mejor y vistiendo ropas mejoradas y de fiesta por solemnidad de las pascuas, dándolas y recibiéndolas con mucho recato y secreto de otros deudos y parientes suyos que guardaban la dicha Ley. 
Dijo que es verdad que sus hermanos Inés y Rodrigo del Campo han guardado la pascua del cordero por la semana santa desde que esta confesante está en su compañía y esta confesante algunas veces del tiempo que tiene dicho a esta parte y por el respeto que tiene dicho, y que este del cordero y del pan cenceño jamás se ha hecho, aunque es verdad que esta confesante ha oído decir a los más viejos que el pan cenceño se había de comer en esta pascua del cordero por todo el tiempo que duraba, y duraba por siete y ocho días. Y preguntada dijo que lo oyó decir a Juana de Mora, su tía, mujer de Juan López de Armenia y a otros viejos y que ha oído decir que hay tres pascuas y entre ellas una que se llama de las cabañuelas, que no sabe cuando cae. Y que es verdad que esta confesante y los dichos sus hermanos Rodrigo e Inés del Campo del tiempo que tiene dicho a esta parte han guardado la pascua del mes de septiembre. Que las dichas pascuas traen a siete y a ocho días y que es verdad que algunos días de las dichas pascuas esta confesante y los dichos Rodrigo y Inés del Campo sus hermanos procuraban de comer mejor en ellas y que ropa no la mudaban. Y que es verdad que se daban las dichas pascuas esta confesante y los dichos sus hermanos con los parientes y primos, hijos de Diego de Mora y de Francisco de Mora, tíos de esta confesante. Y que las dichas pascuas son de la Ley de Moisén. Y parece haber pasado ante Cristóbal Simó[n] Ángel, notario.

En otra audiencia que con la dicha Elvira del Campo tuvieron los dichos Señores Inquisidores en 5 días del mes de Julio del dicho año, por la mañana, en continuación de la dicha acusación. Y respondiendo al $7^{\circ}$ capítulo de ella, que es del tenor siguiente:

Así mismo ha guardado y festificado y vio a otros a guardar los primeros días de la luna nueva en la misma forma y manera que los dichos sábados y pascuas. Y preguntaba a menudo con cautela para advertir a los otros cuando era pascua y la entrada de la luna nueva. Dijo que es verdad que esta confesante preguntaba al dicho Rodrigo del Campo su hermano alguna vez cuando caían las dichas pascuas de la Ley de Moisén y cuando entraba la luna y que esta confesante guardaba los primeros días de la luna. Y que también los guardaban los dichos Inés e Rodrigo del Campo, sus hermanos. Y que esta confesante no tenía cautela en preguntarlo, y que lo de las lunas esta confesante lo preguntaba, porque tenía unas secas que le crecían con las lunas y que por esto preguntaba también cuando entraba la luna.

Preguntada qué le movía a esta confesante a preguntar al dicho Rodrigo del Campo su hermano cuando caían las pascuas de la Ley de Moisén. Dijo "Señor, por saberlo por horas había que había haciendas que hacer y por hacerlas antes que entrase la pascua se lo preguntaba, porque entrada la pascua se las hacían dejar los dichos Rodrigo e Inés del Campo, sus hermanos."

Y respondiendo al $8^{\circ}$ capítulo de la dicha acusación, que es del tenor siguiente: ha ayunado y enseñado ayunar a las dichas personas sus conjuntas y a otros muchos el ayuno mayor de los judíos por el mes de septiembre, no comiendo ni bebiendo en todo el día, hasta salida la estrella por tiempo de diez días continuos, comenzando desde el primero día de la dicha luna, exclusive, y los sábados que tampoco los ayunaba, por ser fiesta de judíos, y entre año otros muchos ayunos que llaman dobles y tres dobles. Y de la Reina Ester que son tres días continuos, y los lunes y jueves de la semana que llaman e son días abondosos, no comiendo los tales días carne si no muerta con ceremonia, la cual pedía a cierta persona que sabía, que la mataba con ella, rezando los tales días principalmente muchas oraciones judiegas, lavándose las manos primero para el efecto, y cada vez que había de comer. 
Dijo que esta confesante ha ayunado el dicho ayuno del mes de septiembre como tiene dicho y que lo hacía por cumplir con los dichos sus hermanos y que esta confesante y los dichos Rodrigo e Inés del Campo sus hermanos algunas veces entre año ayunaban los lunes y jueves, y que esta confesante no ha enseñado a nadie ayunar los dichos ayunos y que es verdad que esta confesante y la dicha Inés del Campo su hermano han ayunado alguna vez ayuno doble que son dos días no comiendo ni bebiendo en todos ellos de sol a sol puesto, y que comían lo que tenían y no otra cosa. Y que es verdad que esta confesante y la dicha su hermana en los otros dichos días rezaban oraciones judiegas, como eran una que comienza: "En mi tribulación llamé.” Otra que comienza: "Señor mío poderoso," otra "Alzaremos ojos al Señor." Las cuales refirió por entero. Y que eran oraciones que esta confesante decía y dice hoy día, y el Credo y el Pater Noster y la Salve y Ave María y Mandamientos.

Preguntada si las dichas oraciones las rezaban otras personas juntamente con esta confesante en los días de ayuno. Dijo que las dichas oraciones las rezaban esta confesante y los dichos Rodrigo e Inés del Campo sus hermanos en los dichos días de ayuno y en otros días y que también los susodichos se lavaban las manos para rezar y comer como esta confesante.

Preguntada si las dichas oraciones y el lavarse las manos para rezar y para comer son ceremonias y cosas de la Ley de Moisén. Dijo que le parecía a este confesante que estas cosas que se le preguntan eran común a todas las gentes y las hacían y decían cristianos y judíos aunque es verdad que son cosas de la Ley de Moisén, aunque esta confesante no se acuerda de hacerlas por eso. Y que entiende que los dichos Rodrigo e Inés del Campo sus hermanos las hacían por de la Ley de Moisén e que esta confesante no las tenía en el pensamiento ni en el corazón.

Preguntada por qué respeto se ayuna este ayuno de la Reina Ester y quién sabe que le haya ayunado: dijo que no sabe el respeto por que se ayuna el dicho ayuno más de que se lo ha visto ayunar a la dicha Inés del Campo su hermana y que este ayuno no se lo ha visto ayunar al dicho Rodrigo del Campo, su hermano.

Y respondiendo al capítulo $10^{\circ}$ de la dicha acusación, que es del tenor siguiente: y por precepto de la dicha Ley de Moisén no come tocino, bazo, morcilla, ni carne trefe, ni mortecina, ni aves ahogadas ni queso el día que había comido carne, ni carne por nueve días continuos después que había muerto alguna persona de su casa. Y si era de fuera el difunto, pero deudo o amigo, no la comía el mismo día que la enterraba.

Dijo que es verdad que esta confesante no comía tocino, bazo ni morcilla, y que carne trefé ni mortecina no la comían esta confesante y los dichos Rodrigo e Inés del Campo sus hermanos, cuando sabían que era la carne trefé o mortecina. Y que después que fue reconciliada esta confesante y está en compañía de los dichos sus hermanos, ha dejado de comer las dichas cosas, como ha hecho las demás que tiene confesadas por cumplir con ellos. Y que aves se ha comido esta confesante degolladas y ahogadas, sin tener cuenta como estuviesen muertas. Y que de lo demás confesado en este capítulo no se acuerda.

Y respondiendo al $11^{\circ}$ capítulo de la dicha acusación, que trata de que comía carne muerta con ceremonia, y purgaba la carne, y de las piernas de los trefés sacaba la landrecilla. Dijo que 
bien sabía esta confesante que en la Ley de Moisén era prohibido el comer las aves que no fuesen degolladas, pero que esta confesante no sabe que fuese prohibido que las matasen las mujeres, ni tenía cuenta con ello. Y que antes que esta confesante fuese reconciliada, es verdad que purgaba y desangraba y desebaba la carne y sacaba la landrecilla de las piernas de las trefés, pero que después acá que está con sus hermanos no lo ha hecho, que su hermana Inés del Campo lo hacía y ella ponía la olla que a esta confesante no la dejaban llegar a esas cosas.

Y respondiendo al $12^{\circ}$ capítulo de la dicha acusación que trata que se juntaban en la casa de esta confesante ciertas personas a oír y ver declarar ciertos pasos de la Biblia, que leía y declaraba cierta persona su conjunta. Dijo que algunos deudos de esta confesante en el Quintanar venían a casa de esta y de sus hermanos a visitarlos, pero no a lo que dice el capítulo, ni vio que el dicho Rodrigo del Campo su hermano leíse ni declarase a ninguna persona cosa alguna. Que bien sabe esta confesante que el dicho su hermano tiene un libro y que entiende que era la Biblia. Y que algunas veces leía para si. Pero que no declaraba nada ni aun leía recio, aunque esta confesante se lo rogaba.

Y respondiendo a capítulo décimo cuarto de la dicha acusación, que trata que recibió cierta suma de dineros y lo ocultó. Dijo que es verdad que el dicho Rodrigo del Campo su hermano les dio a esta confesante y a la dicha Inés del Campo su hermana, cantidad de dineros. No sabe esta confesante cuantos, más de que estaban en oro y que esta confesante confesa que en piezas unas eran sencillas y otras de a dos y que estos dineros se gastaron en comer esta confesante y la dicha Inés del Campo su hermana, y en camas y vestidos, excepto ciertos escudos que a esta confesante le hallaron al tiempo de su prisión. Y dice adelante otras cosas que no son contra la dicha Inés de Campo y al fin de la audiencia dice que esto es la verdad por el juramento que tiene hecho y parece haber pasado ante Cristóbal Simón Ángel, notario.

En la ciudad de Cuenca a 22 días del mes de Agosto de 1591 años, estando el Señor Inquisidor Doctor Francisco de Arganda en la sala e audiencia de la tarde, mandó traer a ella de las dichas cárceles a la dicha Elvira del Campo. Siendo presentes por honestas y religiosas personas, el padre Francisco Escudero y Luis Abad, clérigos presentes que tienen jurado el secreto. Se le dijo que ha acordado en este su negocio que deba decir por descargo de su conciencia e so cargo del juramento que tiene hecho, diga en todo verdad.

Dijo que no tiene que decir más de lo que dicho tiene e luego fue recibido juramento en forma de derecho de la dicha Elvira del Campo, presentes las dichas personas honestas so cargo del cual prometió decir verdad.

Preguntada si se acuerda haber dicho y depuesto por este su proceso alguna cosa contra alguna persona sobre cosas tocantes a la fe. Dijo que bien se acuerda haber dicho y depuesto contra Rodrigo del Campo e Inés del Campo sus hermanos e contra todos sus parientes y refirió en substancia algunas cosas de lo que contra ellos había dicho e pidió se le leyese.

Fue le dicho que el fiscal de este Santo Oficio la presenta por testigo contra todos los que dicho tiene, que este atenta y se le leerá lo que contra ellos tiene dicho y depuesto. Y si en ello hubiere 
que alterar, añadir o enmendar lo haga de manera que en todo diga verdad, porque lo que agora dijere les pasará por juicio.

E luego le fue leída a la dicha Elvira del Campo todo lo que tiene dicho. E después contra los susodichos por este su proceso desde la primera audiencia que con ella se tubo desde 17 días del mes de junio de 1591 años hasta la presente de hoy. Y habiendo dicho que lo había oído y entendido, dijo que aquellas eran sus confesiones y lo que había dicho y depuesto contra los susodichos, y está bien escrito y asentado. Y ella lo había dicho según se le ha leído y en ello no hay que alterar, añadir ni enmendar, porque como estaba escrito e se le ha leído era la verdad. Y en ella dijo, se afirmaba y afirmó. Ratificaba y ratifico y siendo necesario lo decía de nuevo, contra los susodichos y contra las demás personas y cada una dellas de quien tiene dicho y depuesto por este su proceso y no por odio, enemistad que con nadie tenga, sino por descargo de su conciencia e ser así verdad. Fuelle encargado el secreto. Prometió lo y con tanto cesó la audiencia que parece haber pasado ante Alonso de Porreda, notario.

La ciudad de Cuenca a 3 días del mes de octubre de 1591 años, estando el Señor Inquisidor Doctor Francisco de Arganda en su audiencia de la tarde, mandó traer a ella de las dichas cárceles a la dicha Elvira del Campo. E como fue presente se le dijo que ha acordado en este su negocio, que deba decir por descargo de su conciencia, e so cargo del juramento que tiene fecho, diga en todo verdad.

Dijo que no tiene que acordar. E siéndola [sic] dado noticia que el fiscal quiere pedir publicación de testigos, y amonestada sobre ello en forma, respondiendo con juramento a ella y al tercero capítulo del primer testigo que es del tenor siguiente:

Item dijo que sabe que todos los días que quisieren ayunar, podían, como el sábado no ayunasen, y que los de más devoción en la semana eran lunes y jueves, y que así lo había enseñado cierta persona conjunta de la dicha Elvira del Campo a otra, la cual ayunaba algunos días, no comiendo hasta la noche. Y que otras veces ayunaba la dicha persona conjunta dos y tres días. Y que este ayuno le llamaban doble y tres doble, y que en los dichos días no habían de beber.

Dijo que no sabe quién puede ser esa persona y que a Inés del Campo su hermana le ha visto esta confesante ayunar algunas veces pocas dos días arreo sin comer ni beber de sol a sol puesto, salidas ya las estrellas, y que había 17 o 18 años que esta confesante comenzó a ver ayunar a la dicha Inés del Campo su hermana. El dicho ayuno doble pocas veces, como dicho tiene, y que los ayunaba los dichos días postieros del ayuno mayor del mes de septiembre, las veces que los ayunó.

Y respondiendo al $5^{\circ}$ capítulo del dicho testigo, que es del tenor siguiente. Item dijo que sabía y había visto que por el mes de septiembre se ayunaba un ayuno de diez días que entraba en el primero de la luna y que el tal día primero de la luna se holgaba, y que los nueve siguientes se ayunaban como no fuese sábado, aunque también se contaba por ayuno como el primero día de la luna. Y que estos días se ayunaban en la forma que tenía dicho, no comiendo ni bebiendo en todo el día hasta la noche, rezando tres veces la dichas oraciones, lavándose primero cada un las manos. 
Y que este ayuno era el ordinario que ayunaban los que guardaban la Ley de Moisén, como si dijésemos los cristianos la cuaresma. E que pasados los dichos diez días pasaban otros cinco de hueco y entraba la pascua de septiembre a los 15 o 16 de la luna y se guarda siete o ocho días. Y que no estaba este tan bien en memoria, si esta pascua era una de las de siete días, o la que haya 8. Y que esta pascua se guardaba por dar gracias a Dios que había dejado coger los frutos de la tierra, y por solemnidad de ella se visten las mejoras ropas que tienen y comían aventajadamente. Y se huelga no trabajando en los tales días. Y que lo mismo se hace en las otras dos pascuas sobredichas y por solemnidad de ellas.

Dijo que es verdad que los dichos Rodrigo del Campo e Inés del Campo, Alonso del Campo, sus hermanos, Ana de Mora, hija de Juan de Mora, del dicho tiempo de 17 o 18 años a esta parte, esta confesante les ha visto guardar el primer día de la luna y el ayuno del mes de septiembre de diez días, no comiendo ni bebiendo en todo el día hasta la noche, rezando cada uno las oraciones que sabía, tres veces al día, y lavándose las manos cada vez que habían de rezar. Y que es verdad que pasados algunos días después del ayuno -que no tenía memoria cuántos eran- se guardaba una pascua que traía siete o ocho días, y que no se acuerda el respeto porque se guardaba. Y que se vestían y comían mejor en las dichas pascuas. Y que esta confesante hacía algo de ello por cumplir los dichos sus hermanos como dicho tiene. Y que es verda[d] todas las dichas cosas son ceremonias de la dicha Ley de Moisén.

Y respondiendo al noveno capítulo del dicho primero testigo, que es del tenor siguiente. Ítem dijo que sabía y había visto que cierta persona muy conjunta de la dicha Elvira del Campo, muchas veces había leído en un libro de latín, que creía que era la Biblia, y que leía en su casa propia y en otra de otra cierta persona su conjunta, y que declaraba algunas cosas del dicho libro, como eran historias del Testamento Viejo.

Dijo que el dicho Rodrigo del Campo su hermano leía en un libro que entiende esta confesante que era la Biblia, y que algunas veces leía al dicho Alonso del Campo su hermano en el dicho libro por la mañana y otras veces otras horas. Y que no sabe lo que declaraba del dicho libro y que no sabe que el dicho Rodrigo del Campo haya leído a otra persona ninguna en el dicho libro. Y que leía en su propia casa del dicho Rodrigo del Campo. Y que también leía otras veces en otros libros.

Y respondiendo al tercero capítulo del cuarto testigo de la dicha publicación, que es del tenor siguiente. Ítem dijo que sabía que de cierta persona muy conjunta de la dicha Elvira del Campo se decía que tenía un libro que llamaban la Biblia y que en casa de la dicha Elvira del Campo se juntaban algunos deudos suyos y la dicha persona les leía por el dicho libro y que se había oído decir el testigo a cierta persona muy conjunta de la dicha Elvira del Campo y de la que leía. Y que había dicho que los deudos que se juntaban eran los más ancianos y que aunque en particular no sabía cuáles eran, entendía que muchos de los parientes de la dicha Elvira del Campo lo habían hecho y que la dicha persona había dicho que la que leía declaraba en romance lo que leía y que entendía este testigo que serían cosas de la Ley de Moisén.

Dijo que dice lo que dicho tiene y que es verdad que el dicho Rodrigo del Campo su hermano leía la Biblia al dicho Alonso del Campo y a Diego del Campo su hijo, pero no sabe lo que leía ni si se lo declaraba. 
Y respondiendo al cuarto capítulo del dicho cuarto que es del tenor siguiente. Ítem dijo que era cosa muy usada que en casa de la dicha Elvira del Campo y de otros deudos y parientes suyos que nombró que cuando moría alguna persona de las dichas casas, los de aquella donde moría el difunto no comían carne por tiempo de nueve días y que los demás parientes de fuera de casa la dejaban de comer el mismo día, lo que hacían por ceremonia de la Ley de Moisén.

Dijo que no sabe que se haya hecho eso, a lo menos en su casa no se ha hecho, que es verdad que ha oído decir que el día que moría algún difunto no se había de comer carne en aquel día. Y preguntada a quien le oyó decir, dijo que a los más viejos, en particular no se acuerda a quién, y que será ceremonia de la Ley de Moisén, y que lo es.

Y respondiendo al séptimo capítulo del dicho cuarto testigo, que es del tenor siguiente. Ítem dijo que sabía y había visto que luego como fueron presas ciertas personas muy conjuntas de la dicha Elvira del Campo, se habían mudado a casa de cierta persona en compañía juntamente con otra persona su conjunta por el mes de julio de 1590, y que cierta persona que nombró había visto que durante tiempo de dos meses y días más la dicha Elvira del Campo y otra persona su conjunta habían ayunado todos los días arreo de sol a sol, no comiendo ni bebiendo en todo el día hasta salidas las estrellas excepto los sábados y primeros días de la luna que no los ayunaban por ser fiestas de la Ley de Moisén. Y que el dicho ayuno sea de ella y que la dicha persona tenía por cosa cierta que desde que prendieron los primeros de la villa del Quintanar que fueron los hijos de Diego de Mora el año de 1588, había ayunado siempre la dicha Elvira del Campo y la persona su conjunta y otras sus deudos. Y que sabe que ciertas personas las [sic] decían que no ayunasen el dicho ayuno y que sin embargo de ella lo ayunaban. Y que este testigo había oído decir a cierta persona que nombró que la dicha Elvira del Campo y la persona su conjunta decían que por las maldiciones que habían echado a cierta persona le habían prendido porque no la dejaba ayunar. Y que esta es la verdad y no lo dice por odio.

Dijo que es verdad que luego, luego como prendieron a los dichos Rodrigo del Campo e Alonso del Campo, sus hermanos, esta confesante y la dicha Inés del Campo su hermana, se pasaron en casa de Alonso del Campo su hermano en compañía de Isabel Romero su cuñada, y que esto fue a los últimos del mes de julio. Y que hallándose esta confesante con salud, ayunó algunos días arreo no comiendo ni bebiendo $\mathrm{n}$ todo el día hasta la noche por cumplir con las dichas Inés del Campo e Isabel Romero, las cuales también ayunaron algunos días por el dicho tiempo, en la forma que dicho tiene. Y que era ayuno de la Ley de Moisén. Y que por haberles faltado a esta confesante y a la dicha Isabel Romero la salud, dejaron de ayunar y que la dicha Ynés del Campo ayunó algún ratito de días, no sabe determinadamente cuántos, ni los que esta confesante y la dicha Isabel Romero ayunaron. Y al cabo de la audiencia dice "y esta es la verdad" y para el juramento que tiene hecho. Y parece haber pasado ante Cristóbal Simón Ángel, notario.

En la ciudad de Cuenca a 30 días del mes de octubre de 1591 años, estando el Señor Inquisidor Francisco de Arganda que al presente reside solo en este Santo Oficio en su audiencia de la mañana, mandó traer a ella de las dichas cárceles a la dicha Elvira del Campo. E como fue presente se le dijo que ha acordado en este su negocio que deba decir por descargo de su conciencia, e so cargo del juramento que tiene fecho diga en todo verdad. 
Y dijo que no se ha [a]cordado de otra cosa. E siéndole dada noticia que el fiscal de este Santo Oficio quería pedir segunda publicación de testigos. Y siendo amonestada en forma sobre ella y recibido juramento en forma de derecho, respondiendo a ella y al cuarto capítulo del décimo cuarto testigo que es del tenor siguiente. Ítem dijo que sabía y había visto que la dicha Elvira del Campo y otras personas sus muy conjuntas por solemnidad de las pascuas y sábados algunas veces holgaban no trabajando y comían mejor y vestían aventajadamente.

Dijo que es verdad que esta confesante y sus hermanos Alonso del Campo, Rodrigo del Campo e Inés del Campo, por solemnidad de las pascuas de la Ley de Moisén e de los sábados algunas veces no trabajaban y comían y vestían mejor y que lo mismo entiende hacían todos sus deudos.

Y respondiendo al quinto capítulo del dicho $14^{\circ}$ testigo, que es del tenor siguiente. Ítem dijo que sabía y había visto que la dicha Elvira del Campo y otra cierta persona su muy conjunta de 20 años a esta parte, poco más o menos, dejaban los candiles encendidos los viernes en las noches hasta que ellos se morían y que entendía que lo habían hecho por honra del sábado. Y que también les había visto barrer y limpiar la casa algunas veces los viernes en las tardes por el dicho respeto.

Dijo que es verdad que los viernes en las tardes Inés del Campo, su hermana de esta confesante, por honra del sábado barría y limpiaba la casa y los viernes en las noches dejaba el candil encendido algunas veces hasta que él se moría y que esta confesante la ayudaba a las dichas cosas como lo hacía a las demás que se hacían en casa y que bien sabía esta confesante que era cerimonia de la Ley de Moisén. Y que la dicha Inés del Campo las hacía por la Ley, y esta confesante por el respeto que tiene dicho.

Y respondiendo al décimo capítulo del dicho $14^{\circ}$ testigo, que es del tenor siguiente. Ítem dijo este testigo que entendió que la dicha Elvira del Campo y la dicha persona su muy conjunta y las demás de quien tiene dicho echaban sal en la carne cuando la lavaban para desangrarla y purgarla porque este testigo había oído decir que así se había de hacer conforme a las demás ceremonias que tenía declaradas. Dijo que su hermana de esta confesante ponía siempre la olla y purgaba y desangraba la carne con sal y agua.

Respondiendo al undécimo capítulo del dicho $14^{\circ}$ testigo, que es del tenor siguiente. Ítem dijo que la dicha Elvira del Campo y la dicha su conjunta persona preguntaba a otra su muy conjunta algunas veces cuando eran las dichas pascuas, que el testigo tenía dicho que holgaban [y] primeros días de la luna del tiempo que tenía dicho a esta parte y que esta es la verdad, y no lo dice por odio.

Dijo que verdad que esta confesante y la dicha Inés del Campo su hermana preguntaban al dicho Rodrigo del Campo su hermano cuando caían las lunas y las pascuas y él se lo decía. Y que todo lo que tiene confesado haber hecho esta confesante en compañía de los dichos sus hermanos ha sido de veinte años a esta parte [ $=1571]$, hasta el año inmediato a esta parte, poco más o menos, por el respeto que tiene dicho de cumplir con ellos y con los más deudos que vivían en la Ley de Moisén. Y que esto es la verdad, do cargo del juramento que tiene hecho. Y parece haber pasado ente Cristóbal Simón Ángel, notario. 
En la audiencia a 4 días del mes de diciembre de 1591 años, estando el Señor Inquisidor Doctor Francisco de Arganda en su audiencia de la tarde, mandó traer a ella de las dichas cárceles a la dicha Elvira del Campo, e como fue presente se le dijo si ha acordado alguna cosa en este su negocio que deba decir por descanso de su conciencia. E so cargo del juramento que tiene hecho diga en todo verdad. Dijo que no ha acordado de ninguna cosa.

Ítem el testigo décimo jurado y ratificado en tiempo y en forma añadiendo a su primera deposición por el mes de noviembre de 1591. Dijo que sabía y había visto que habría tiempo de 12 o 13 años, que estando muy mala cierta persona que nombró, hija de cierta persona muy conjunta de Elvira del Campo, la dicha Elvira del Campo y otra cierta muy su conjunta habían ido a casa de la dicha persona enferma juntamente con otra cierta persona conjunta de todos, y que luego como llegaron a la dicha casa la dicha Elvira del Campo había entrado en el aposento donde estaba en la cama la dicha enferma. Y hablando con otra cierta persona le había dicho que se levantase porque no muriese en el dicho aposento la dicha persona enferma. Porque si allí moría sería necesario lavar toda la ropa de la cama, y todo lo que estaba colgado en el aposento. Y que también sería necesario lavar a otras ciertas personas que estaban en el dicho aposento. Y que así la dicha persona se había levantado y tomado la dicha enferma y la había llevado a otro aposento de la dicha casa que declaró. Y que juntamente había ido con la dicha persona la dicha Elvira del Campo. Y estando presentes las dichas personas y otra que nombró, la dicha Elvira del Campo había [łavado] derramado el agua de los cántaros, y los había sacado del dicho aposento dejando solo en el uno con agua y unas toallas de lino encima. Y que otra persona conjunta de todos se había hallado presente había ayudado a la dicha Elvira del Campo a derramar el agua. Y que todos los que se habían hallado presentes lo habían aprobado y tenido por bueno al parecer de este testigo. Porque no habían dicho cosa encuentra.

Dijo que lo que sea verdad de lo contenido en este capítulo es que estando una sobrina de esta confesante, hija de Alonso del Campo, su hermano, muy mala, que no se acuerda cómo se llamaba, aun que le parece que se llamaba Isabel. Una noche que ya era oscuro, no se acuerda qué hora era, esta confesante llamada por alguna persona de casa del dicho Alonso del Campo su hermano no se acuerda quién. Fue allí a la dicha hora y murió la dicha niña aquella noche. Y que de esto se acuerda y no de otra cosa ninguna de las que dice el capítulo.

E que ahora se recuerda que cuando esta confesante fue a ver a a la dicha Isabelica su sobrina a casa de dicho Alonso, fue allí y se halló a su muerte Inés del Campo hermana de este confesante y que no se acuerda si fue allí Rodrigo del Campo su hermano, que por antojo le parece que no. Y al cabo de la audiencia dice "y esta es la verdad" y parece haber pasado ante Cristóbal Simón Ángel, notario.

En la ciudad de Cuenca a 11 días del mes de diciembre de 1591 años, estando el Señor Inquisidor Dr. Francisco de Arganda en su audiencia de la mañana, mandó traer a ella de las dichas cárceles a la dicha Elvira del Campo. E como fue presente se le dijo si ha acordado alguna otra cosa en este su negocio que deba decir por descargo de su conciencia. E so cargo del juramento que tiene fecho, diga que es verdad. Dijo que no se ha acordado de ninguna cosa.

E luego fueron mandados entrar en la dicha audiencia al Padre Francisco Escudero e Miguel Guijarro, presbíteros, personas honestas de este Santo Oficio que tienen jurado el secreto en 
presencia de los cuales fue re habido juramento en forma de derecho de la dicha Elvira del Campo so cargo del cual juro prometió verdad.

Preguntada si se acuerda haber dicho por este su proceso alguna cosa contra alguna persona, respondiendo a la adición del testigo $10^{\circ}$ que en la audiencia pasada se le dio. Dijo que no se acordaba bien de lo que dijo que pedía se le leyese.

Fue le dicho que el fiscal de este Santo Oficio la presenta por testigo contra Inés del Campo su hermana e Juana de Mora mujer de Juan López de Armenia que lo que contra ellas tiene dicho en la dicha audiencia que este atenta en se le leerá y si en ello hubiere que alterar, añadir e enmendar lo haga de manera que en todo diga verdad y se afirme y ratifique en ello porque lo que ahora dijere les pasará per juicio.

E luego fue leído a la dicha Elvira del Campo lo que tiene dicho contra las susodichas en las dichas audiencias precedente de verbo ad verbum, según que en ello se contiene. E habiendo dicho que lo habrá oído y entendido, dijo que aquello era lo que ella había dicho contra las dichas Inés del Campo su hermana e Juana de Mora, y estaba bien escrito y en ello no había que alterar, añadir ni enmendar y en ello se afirmaba y afirmó, ratificaba y ratificó e siendo necesario lo decía de nuevo contra la dichas Inés del Campo y Juana de Mora. E no por odio y no por ser verdad. Fue le encargado el secreto y metió lo dicho ante mi Cristóbal Simón Ángel notario.

Concuerda con el original

Pedro Pérez de Ullibarri notario 


\section{A list of the Inquisitorial files used in this study.}

a) Archivo Diocesano de Cuenca, Inquisición

Libro 352: (Relación de causas que se han remetido a los Señores del Consejo desde 1583 hasta 1600)

Leg. 11, no. 228: Catalina Afonso (1493)

Leg. 325, no. 4654: Alonso del Campo II ( $\mathrm{FMM}^{664}$, s first cousin once removed)

Leg. 323, no. 4645: Ana del Campo (FMM's first cousin once removed)

Leg. 324, no. 4653: Diego del Campo (FMM's first cousin once removed)

Leg. 320, no. 4620: Inés del Campo (FMM's first cousin)

Leg. 325, no. 4663: Juan del Campo (FMM's first cousin once removed)

Leg. 327, no. 4690: Pedro del Campo

Leg. 330, no. 4719: Pedro del Campo (FMM's first cousin once removed)

Leg. 321, no. 4627: Rodrigo del Campo (FMM's first cousin)

Leg. 327, no. 4691: Leonor Enríquez (FMM's wife)

Leg. 330, no. 4721: Beatriz Gómez de Bedoya (widow of Juan de Mora Carrillo, FMM's first cousin)

Leg. 283, no. 3946: Juan López de Armenia el viejo (FMM's uncle by marriage)

Leg. 329, no. 4706: Alonso Martínez de Mora (FMM's first cousin)

Leg. 324, no. 4652: Antonio Martínez de Mora (FMM's first cousin)

Leg. 315, no. 4562: FMM (first proceso)

Leg. 328, no. 4704: FMM (second proceso)

Leg. 281, no. 3907: Alvaro de Mora (FMM's first cousin)

Leg. 320, no. 4619: Ana de Mora (FMM's first cousin)

Leg. 318, no. 4586: Beatriz de Mora (Francisco de Mora's first cousin)

Leg. 277, no. 3830: Catalina de Mora (FMM's sister)

Leg. 326, no. 4682: Catalina de Mora (Carrillo) (FMM's first cousin)

Leg. 321, no. 4621: Cristóbal de Mora Molina (FMM's first cousin)

Leg. 319, no. 4607: Diego de Mora (FMM's father)

Leg. 246, no. 3288: Diego de Mora (FMM's first cousin)

Leg. 314, no. 4555: Francisca de Mora (FMM's sister)

Leg. 331, no. 4734b: Francisca de Mora (FMM's sister)

Leg. 711, no. 753: Francisco de Mora the Elder (FMM's uncle)

Leg. 748b, no. 100 (ff. 169-267): Francisco de Mora the Elder (FMM's uncle)

Leg. 320, no. 4618: Hernando de Mora (FMM's uncle)

Leg. 330, no. 4707: Hernando de Mora "Pastor" (FMM's nephew)

Leg. 324, no. 4651: Inés de Mora (FMM's aunt)

Leg. 324, no. 4647: Isabel de Mora (FMM's first cousin)

Leg. 317, no. 4585: Isabel de Mora (FMM's sister)

Leg. 234, no. 2996: Juan de Mora (FMM's uncle)

Leg. 322, no. 4632: Juan de Mora (FMM's uncle)

Leg. 318, no. 4587: Juan de Mora (FMM's brother)

Leg. 328, no. 4703: Juan de Mora el albañir (FMM's first cousin)

Leg. 235, no. 3010: Juana de Mora (1564) (FMM's aunt)

${ }^{664} \mathrm{FMM}=$ Francisco de Mora Molina 
Leg. 232, no. 2919: Juana de Mora and Marí López de Mora (FMM's aunts)

Leg. 314, no. 4554: Juana de Mora (FMM's first cousin)

Leg. 234, no. 2987: Lope de Mora (FMM's uncle)

Leg. 322, no. 4635: Lope de Mora (FMM's first cousin)

Leg. 316, no. 4572: Luisa de Mora (FMM's sister)

Leg. 314, no. 4553: Luisa de Mora (FMM's first cousin)

Leg. 313, no. 4549: María de Mora (FMM's sister)

Leg. 712, no. 785: Pedro de Mora (FMM's non-existent half-brother)

Leg. 321, no. 4620b: Catalina de Mora Carrillo (FMM's first cousin)

Leg. 329, no. 4703b: Francisco de Mora Carrillo (FMM's first cousin)

Leg. 327, no. 4689: Isabel de Mora Carrillo (FMM's first cousin)

Leg. 331, no. 4733: Juan de Mora Carrillo (FMM's first cousin)

Leg. 391, no. 4734: Luisa de Mora Carrillo (FMM's second cousin)

Leg. 322, no. 4631: María de Mora Carrillo (FMM's first cousin)

Leg. 321, no. 4626: Catalina Navarra (FMM's first cousin)

Leg. 323, no. 4639: Francisco Navarro (FMM's grandnephew)

Leg. 323, no. 4640: Francisca Rodríguez (Mora family retainer)

Leg. 59, no. 865: Pedro Rodríguez de Villanueva

Leg. 70, no. 107: Pedro Rodríguez de Villanueva

Leg. 323, no. 4642: Isabel Romero (Alonso del Campo's second wife)

Leg. 551, no. 6918: Leonor Ruiz (FMM's first cousin and wife of FMM's first cousin Lope de Mora)

Leg. 315, no. 4560: Hernando and Pedro de Sauca (FMM's brothers-in-law)

Leg. 330, no. 4722: Isabel de Villescusa (Alonso del Campo's first wife)

Leg. 328, no. 4705: Catalina de Villanueva (FMM's aunt)

Leg. 319, no. 4606: María de Villanueva (FMM's mother)

\section{b) Archivo Histórico Nacional (Madrid), Inquisición}

Leg. 138, no. 7: Elvira del Campo (FMM's first cousin)

Leg. 138, no. 8: Juan del Campo I (FMM's first cousin)

Leg. 1930, no. 23: Catalina García (1493)

Leg. 154, no. 365: Juan González (1496)

Leg. 162, no. 12: Juan López de Armenia II (FMM's first cousin)

Leg. 181, no. 14: Elvira Ruiz (FMM's first cousin)

Leg. 181, no. 15: Francisco Ruiz de Armenia (father of Elvira Ruiz)

Leg. 187, no. 7: Alonso de la Vega (FMM's uncle by marriage to his aunt Elvira de Mora)

Leg. 187, no. 8: Francisco de la Vega I (FMM's first cousin)

Leg. 188, no. 1: Francisco de la Vega II (Veguilla)

Recibido: 29/01/2006

Aceptado: 01/09/2006 